\title{
Molecular detection of Clostridium perfringens toxinotypes, Enteropathogenic Escherichia coli, rotavirus and coronavirus in diarrheic fecal samples of neonatal goat kids
}

\author{
Desh D. Singh", Rajveer S. Pawaiya, Kumaresan Gururaj*, \\ Neeraj K. Gangwar, Anil K. Mishra, Dimple Andani, Manoj K. Singh, \\ Saket Bhushan, and Ashok Kumar
}

Division of Animal Health, ICAR-Central Institute for Research on Goats, Makhdoom, Farah, Mathura, Uttar Pradesh, India

\begin{abstract}
SINGH, D. D., R. S. PAWAIYA, K. GURURAJ, N. K. GANGWAR, A. K. MISHRA, D. ANDANI, M. K. SINGH, S. BHUSHAN, A. KUMAR: Molecular detection of Clostridium perfringens toxinotypes, Enteropathogenic Escherichia coli, rotavirus and coronavirus in diarrheic fecal samples of neonatal goat kids. Vet. arhiv 88, 1-20, 2018.
\end{abstract}

\section{ABSTRACT}

In the present study, out of 1156 neonatal goat kids, 238 showing clinical diarrhea were used for detection of toxinotypes of Clostridium perfringens, Enteropathogenic E. coli (EPEC), Group A rotavirus (GARV) and Bovine coronavirus $(\mathrm{BCV})$. Isolation and toxinotyping of isolates were done by multiplex Polymerase chain reaction (PCR) using primers for $c p a, c p b, c p b 2$, etx and iap genes. For EPEC, isolation and identification were done using $b f p$ A gene and SYBR green based real time PCR (qPCR). GARV and BCV were detected, by onestep RT-PCR (osRT-PCR). The incidence of C. perfringens was $15.13 \%$ with $75 \%$ isolates toxinotype A, $25 \%$ type $\mathrm{D}$ and $61.11 \%$ of isolates carrying the $\beta 2$-toxin gene. The incidence of EPEC was $68.07 \%$ based on qPCR, whereas $21.85 \%$ were positive for GARV and $15.97 \%$ for BCV by osRT-PCR. There was mixed infection of $C$. perfringens and $\mathrm{EPEC}$ in $11.76 \%$ and $3.78 \%$ for $C$. perfringens and GARV and $2.1 \%$ of C. perfringens and $\mathrm{BCV}$. EPEC and GARV was $19.74 \%$ and EPEC plus BCV positivity was $11.34 \%$. GARV and BCV was $5.88 \%$, and $4.20 \%$ had mixed infection of EPEC, GARV and BCV. Of the total diarrheic kids sampled, $0.84 \%$ had mixed infection of $C$. perfringens, GARV, BCV and EPEC. On the basis of the above findings, it may be concluded that isolation, multiplex PCR and real time PCR facilitated the characterization of circulating C. perfringens toxinotypes and EPEC in goats reared under semi-arid conditions. The importance of enteritis caused by GARV and $\mathrm{BCV}$ and their role in mixed infection in goats requires extensive screening and pathogenicity studies to associate the symptoms with disease.

Key words: C. perfringens; toxinotypes; E. coli; rotavirus; coronavirus; neonatal diarrhea; goats

\footnotetext{
*Corresponding author:

Kumaresan Gururaj, M.V.Sc., PhD., (Veterinary Microbiology), Scientist, ICAR-Central Institute for Research on Goats, Makhdoom, Farah, Mathura (Uttar Pradesh) 281122, India, Phone: +91 5652763 380; Fax: +91 5652763 246; E-mail: guruvet@gmail.com
} 
D. D. Singh et al.: Molecular detection of Clostridium perfringens toxinotypes, EPEC, rota- and coronavirus in diarrheic goat kids

\section{Introduction}

The role of goats in the human food chain is growing day by day due to the popularity of goat rearing in the developing economies. The incidence of diseases and parasitic infestations is one of the major constraints in the development of goat enterprises, contributing towards substantial losses to the goat keepers. In addition, parasitic diseases, including coccidial infections, affect goat rearing economically due to their clinical form, which causes diarrhea as well as the subclinical form which leads to poor performance (CHARTIER and PARAUD, 2012). A retrospective review of data over 25 years, carried out on organized farms in India revealed that $43.67 \%$ of mortality in goats is caused by enteritis, to which intestinal infections contributed most followed by gastro-intestinal parasites (PAWAIYA et al., 2017). Enterotoxaemia affects small ruminants worldwide, causing heavy mortality and significant economic impact, but studies in goats are relatively scant compared to sheep (SUMITHRA et al., 2013). Clostridium perfringens is considered to be part of the normal flora in various animal species including sheep and goats (McCLANE et al., 2005). Enterotoxaemia is caused by the slowing down of intestinal peristalsis, which induces the proliferation of a large amount of toxin production (SONGER, 1996). C. perfringens causes enterotoxaemia, an economically important devastating disease of sheep and goats (NIILO, 1980), and the most important cause of sudden death in goats of different ages. The late log phase of bacterial growth is optimum for production of toxins, such as $\alpha, \beta, \beta 2, \varepsilon$ and $\mathrm{\imath}$ by $C$. perfringens (SAYEED et al., 2005). Escherichia coli of eight pathovars causes a wide range of diseases that affect humans and animals globally (CROXEN and FINLAY, 2010), with the enteropathogenic E. coli (EPEC) being a major cause of fatal diarrhea in developing countries (NATARO and KAPER, 1998; BUGAREL et al., 2011). In the recent past, studies envisaged the presence of one or more virulent genes, including stx 1 , stx 2 , eaeA, and $h l y A$, in field isolates from goats (WANI et al., 2006), and a 12.5\% incidence of EPEC isolates in diarrheic lambs (BHAT et al., 2008). Bundle forming pilin (BFP) protein encoded by bundle forming pilin ( $b f p$ ) gene plays a significant role in adherence and micro-colonization in the small intestine, that culminates into clinical diarrhea (GIRON et al., 1991). Rotavirus gastroenteritis is a worldwide disease primarily affecting infants, young children and young animals, with susceptibility decreasing with the progress of age (ESTES and KAPIKIAN, 2007) with Group A Rotavirus (GARV) infections leading to severe diarrhea and economic losses in intensively reared livestock (PAPP et al., 2013). Diarrhea in Black Bengal goat kids is most frequently found associated with GARV (DEY et al., 2007). Bovine coronavirus $(\mathrm{BCV})$ is a major viral pathogen associated with neonatal calf diarrhea (NCD) (MEBUS et al., 1973), with very few reports of its incidence in goats (HUOCHUN et al., 1990; MUÑOZ et al., 1996; OZMEN et al., 2006; YANG et al., 2008) and sheep (ANDRÉS et al., 2007). To the best of our knowledge, there has been no organized study of BCV in neonatal goat kids as far as India is concerned. Enteric BCV replicates in the epithelial cells of the gut, destroying the villi, resulting in severe, often bloody diarrhea in calves 
D. D. Singh et al.: Molecular detection of Clostridium perfringens toxinotypes, EPEC, rota- and coronavirus in diarrheic goat kids

(CLARK, 1993). In view of the scarce literature and information, the present study was undertaken regarding the detection of toxinotypes of clostridial toxins, EPEC, GARV, $\mathrm{BCV}$ and their mixed infection in neonatal goat kids.

\section{Materials and methods}

Collection of samples. During the period from January 2015 to July 2016, a population of 1156 neonatal goat kids of 0-3 months of age were examined for diarrhea, in the semiarid region of the Mathura and Agra districts of Uttar Pradesh and the adjoining Bharatpur district of the Rajasthan states of India. The study area is situated in the semi-arid zone of western Uttar Pradesh and eastern Rajasthan of India $\left(27.10^{\circ}-27.50^{\circ} \mathrm{N}, 77-78.0^{\circ} \mathrm{E}\right)$ at about 169.2 Meters (MSL). The climate is semi-arid with temperatures varying from $28{ }^{\circ} \mathrm{C}$ to over $45^{\circ} \mathrm{C}$ in summer (April to July) and 6 to $24{ }^{\circ} \mathrm{C}$ in winter (NovemberFebruary). The average annual rainfall is $750 \mathrm{~mm}$ with wet days from June to September. The kidding season in these areas mostly falls during the period between February to May and August to October. Among the population studied, 238 kids showed diarrhea, with clinical symptoms including weakness, dehydration and a soiled perineal region. Fecal swabs were collected from all clinically diarrheic neonatal goat kids using sterile swabs (Himedia). The collected swabs were kept in an ice pack and brought to the Pathology Laboratory, Division of Animal Health, ICAR-Central Institute for Research on Goats, Makhdoom, Farah, Mathura (UP), India. The swab samples were suspended in $2.0 \mathrm{~mL}$ sterile double glass distilled water and stored in Eppendorf tubes at $4{ }^{\circ} \mathrm{C}$ for clostridial culture, and $-20^{\circ} \mathrm{C}$ for DNA and RNA isolation.

Bacteriological studies. Fecal suspensions were inoculated into Robertson cooked Meat Media (RCMM) under anaerobic conditions for $C$. perfringens. Positive samples showed gas production, and bacterial presence was confirmed by Gram's staining. The supernatant fluid from RCMM was subsequently inoculated to $5 \%$ defibrinated sheep blood Brucella agar with Vitamin $\mathrm{K}_{1}$, Hemin and selective clostridial supplements (CLSBBA). The purity of the culture was assessed by Gram's staining. To further confirm the culture, a single colony was streaked on egg yolk agar (EYA) to identify lecithinase activity.

The culture supernatant containing the prototoxin was activated by trypsin treatment (HABEEB, 1969). The activated toxin was then titrated in a mouse using 10 fold dilutions by the intraperitoneal route, to study the isolates' potential for producing epsilon toxin.

All fecal suspensions were inoculated on blood agar (5\% de-fibrinated sheep blood) followed by identification of lactose fermenting (LF) pink colonies by sub-culturing an individual colony on MacConkey's agar. The LF colonies were further re-inoculated on EMB agar. The colonies with metallic sheen and those selected on the basis of preliminary screening by biochemical tests, gram staining, motility, and their isolates were used for molecular detection of EPEC. 
D. D. Singh et al.: Molecular detection of Clostridium perfringens toxinotypes, EPEC, rota- and coronavirus in diarrheic goat kids

Isolation of bacterial DNA. DNA purification was done from RCMM culture supernatant for $C$. perfringens and fecal suspensions for EPEC using a commercially available kit (QIAamp ${ }^{\circledR}$ DNA Mini Kit) following the manufacturer's instructions. The quantity and quality of DNA was assessed at A260nm and A260/280 using a biophotometer plus (Eppendorf, USA).

Polymerase Chain Reaction (PCR). A Multiplex PCR kit (Qiagen, USA) was used for amplifying toxin genes of $C$. perfringens. Oligonucleotides for $c p a, c p b, c p b 2$, etx and iap were used for toxinotyping (VAN ASTEN et al., 2009) (Table 1). The positive control used for the current study was $C$. perfringens type $\mathrm{D}$, which was confirmed by sequencing the epsilon toxin complete coding sequencing, and accessioned by NCBI GenBank Accession: KY938006, and the characterized strain was also deposited in the National center for veterinary type culture (Accession no. VTCCBAA1197), ICAR-NRCE, Hisar, India. The negative controls were included in the reaction as no template control (NTC).

Table 1. Toxinotyping primers

\begin{tabular}{|c|c|c|c|c|}
\hline Toxin & Primer & Primer Sequence $\left(5^{\prime}-3^{\prime}\right)$ & $\begin{array}{l}\text { Amplicon } \\
\text { size (bp) }\end{array}$ & Reference \\
\hline Alpha & $c p a$ & $\begin{array}{l}\text { F - GCTAATGTTACTGCCGTTGA } \\
\text { R- CCTCTGATACATCGTGTAAG }\end{array}$ & 324 bp & \multirow{5}{*}{$\begin{array}{l}\text { Van Asten et al. } \\
\text { (2009) }\end{array}$} \\
\hline Beta & $c p b$ & $\begin{array}{l}\text { F- GCGAATATGCTGAATCATCTA } \\
\text { R- GCAGGAACATTAGTATATCTTC }\end{array}$ & $195 \mathrm{bp}$ & \\
\hline Beta 2 & $c p b 2$ & $\begin{array}{l}\text { F-AAATATGATCCTAACCAAMAAA } \\
\text { R- CCAAATACTYBTAATYGATGC }\end{array}$ & 548 bp & \\
\hline Epsilon & etx & $\begin{array}{l}\text { F-TGGGAACTTCGATACAAGCA } \\
\text { R-AACTGCACTATAATTTCCTTTTCC }\end{array}$ & 376 bp & \\
\hline Iota & iap & $\begin{array}{l}\text { F- AATGGTCCTTTAAATAATCC } \\
\text { R- TTAGCAAATGCACTCATATT }\end{array}$ & 272 bp & \\
\hline
\end{tabular}

$(\mathrm{F})=$ Forward primer; $(\mathrm{R})=$ Reverse primer

SYBR green real time PCR for EPEC detection. Primers were designed for the amplification of the $b f p$ A gene viz., $b f p$ A F: 5'-ATGGTGCTTGCGCTTGCTGC-3', $b f p$ A R: 5'-AATCCACTATAACTGGTCTGC-3', for diagnosing EPEC isolates of E. coli using BioEdit-v.7.2.5 software (HALL, 1999) with the nucleotide database sequences from the NCBI database. A conventional gradient PCR was conducted to check the quality of the reaction and amplification of $158 \mathrm{bp}$ amplicon. The real time PCR data were analyzed by taking a Cq value between 20-30 cycles with an RFU value close to $10^{3}$ at the X-axis (Amplification plot), accompanied by a melt curve analysis in which a melting peak of approximately $85^{\circ} \mathrm{C}$ (X-axis) lying above the threshold of 150 on the Y-axis (which represents a negative derivative of fluorescence over temperature versus temperature $[-\mathrm{d}(\mathrm{RFU}) / \mathrm{dT}])$ were considered positive amplicons. The other noisy peaks less than 
D. D. Singh et al.: Molecular detection of Clostridium perfringens toxinotypes, EPEC, rota- and coronavirus in diarrheic goat kids

$85^{\circ} \mathrm{C}$ and below the threshold of 150 on the Y-axis $[-\mathrm{d}(\mathrm{RFU}) / \mathrm{dT}]$ were primer dimers. The positive control used in the current study was the Escherichia coli strain possessing the bundle forming pilin protein gene (bfp) characterized, deposited and accessioned (Accession no. VTCCBAA1160) from the National Center for Veterinary type culture (NCVTC) repository, ICAR-NRCE, India. The negative control used was a non-EPEC strain of $E$. coli, validated and maintained in the laboratory.

Hence, a SYBR green-chemistry based real time PCR assay was developed and standardized for differentiation of EPEC and non-EPEC isolates.

The reaction was carried out in a 2xUniversal SYBR green master mix (Roche diagnostics, Switzerland) with 5 Pico mole concentrations of each primer, along with 1 $\mu \mathrm{L}$ of template DNA per reaction, and the standardized cycling condition is given below:

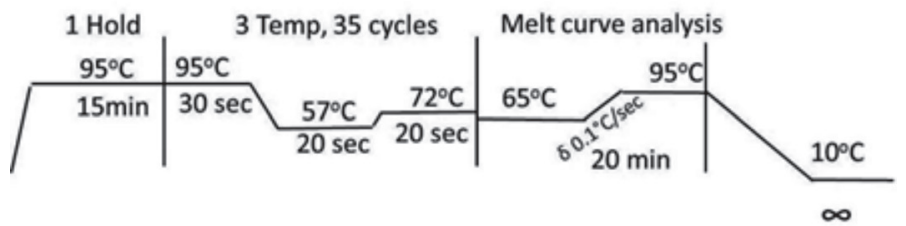

$R N A$ extraction for GARV and BCV. RNA isolation was done from fecal washings by adding TRI reagent (Sigma-Aldrich, USA), essentially following the manufacturer's protocol. The RNA was pelleted, reconstituted in DEPC water and checked for purity using a microphotometer reading at A260/280 with a ratio above 2. The double stranded viral RNA genome of Rota virus was denaturated by Dimethyl sulfoxide (DMSO) treatment at $95{ }^{\circ} \mathrm{C}$ for $10 \mathrm{~min}$.

One-step RT-PCR for GARV and BCV. RT-PCR amplification of target genes for GARV and BCV was done directly from fecal RNA using specific primers (MATTHIJNSSENS et al., 2008; TSUNEMITSU et al., 1999) (Table 2) by SuperScript ${ }^{\circledR}$ III One Step RT-PCR system with Platinum ${ }^{\circledR}$ Taq High Fidelity kit (Invitrogen, USA) as per the manufacturer's instructions. For positive controls, standard commercially available vaccine strains were used, whereas negative controls were kept as no-template controls.

Table 2. Primers used for GARV and BCV in osRT-PCR

\begin{tabular}{|c|c|c|c|c|c|}
\hline Virus & Target gene & Primer & Sequence $\left(5^{\prime} \rightarrow 3^{\prime}\right)$ & $\begin{array}{c}\text { Product } \\
\text { length } \\
\text { (bp) }\end{array}$ & Reference \\
\hline \multirow{2}{*}{ GARV } & \multirow{2}{*}{ VP6 } & GEN_VP6F & GGCTTTWAAACGAAGTCTTC & \multirow{2}{*}{928} & \multirow{2}{*}{$\begin{array}{c}\text { Matthijnssens } \\
\text { et al. (2008) }\end{array}$} \\
\hline & & GARVP6-928R & GGYGTCATATTYGGTGG & & \\
\hline \multirow{2}{*}{$\mathrm{BCV}$} & \multirow{2}{*}{ Nucleocapsid } & BCV-N-F & GCCGATCAGTCCGACCAATC & \multirow{2}{*}{407} & \multirow{2}{*}{$\begin{array}{l}\text { Tsunemitsu et } \\
\text { al. (1999) }\end{array}$} \\
\hline & & BCV-N-R & AGAATGTCAGCCGGGGTAT & & \\
\hline
\end{tabular}


D. D. Singh et al.: Molecular detection of Clostridium perfringens toxinotypes, EPEC, rota- and coronavirus in diarrheic goat kids

\section{Results}

Incidence of diarrhea in neonatal kids. Out of the 1156 neonatal goat kids of 0-3 months of age, $20.59 \%$ were diarrheic, of which $10.47 \%$ males and $10.12 \%$ females. Among the kids observed with apparently clinical diarrhea, 9.78\% were $0-1$ month of age, with $6.31 \%$ males and $3.46 \%$ females, and $10.81 \%$ of $1-3$ months of age, with $4.24 \%$ males and $6.57 \%$ females. Among the total diarrheic animals sampled (238), $47.48 \%$ were $0-1$ month and $52.52 \% 1-3$ months of age.
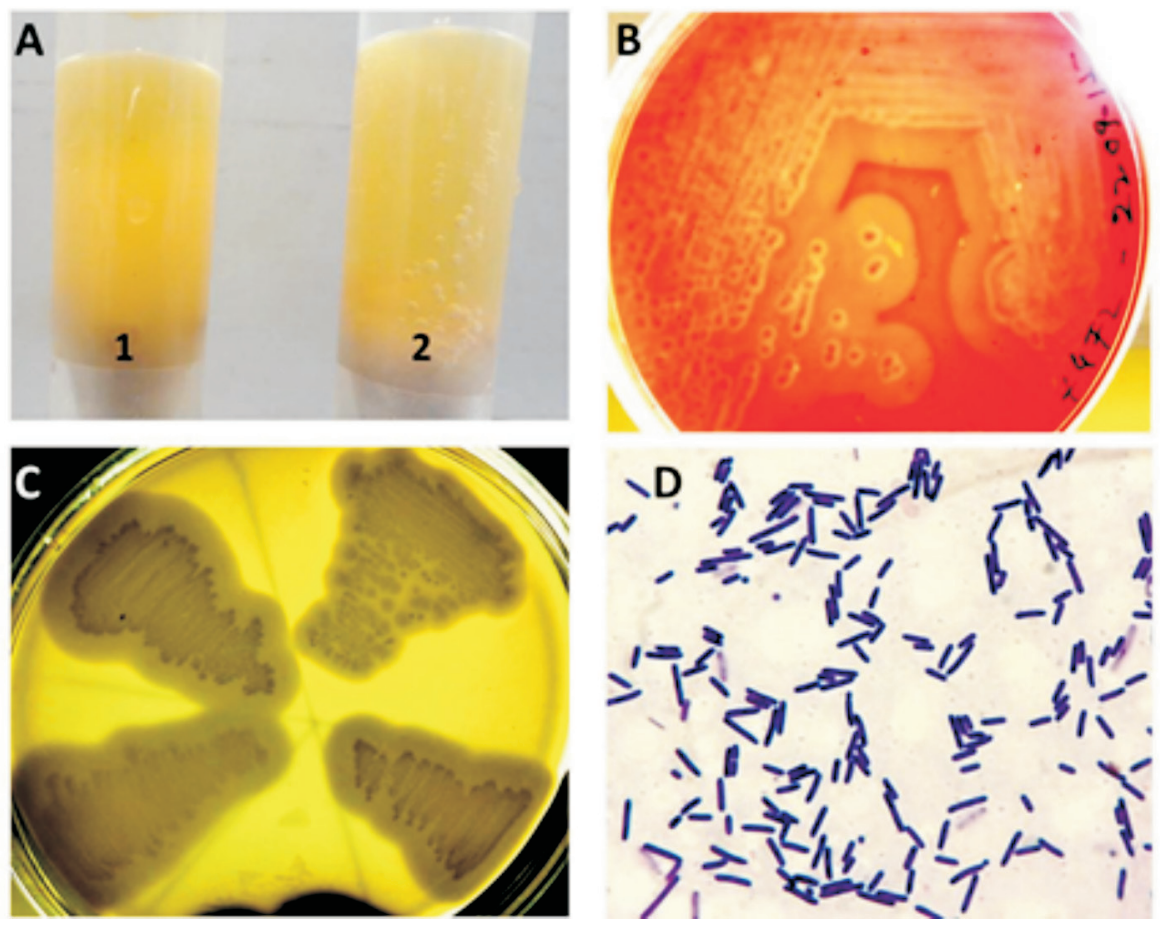

Fig. 1. Bacteriological studies of C. perfringens isolate showing (A) RCMM with gas production;

(B) Double hemolysis and colony morphology; (C) Lecithinase activity on EYA; (D) Gram positive rods

Isolation and toxinotyping of C. perfringens. In RCMM, out of 238 diarrheic samples, 36 showed gas production (Fig. 1A) and, confirmed by Gram's staining, showed stumpy or slender Gram positive rods with truncated or rounded ends (Fig. 1D). The results of the positive samples and incidence percentage (\%) are presented in Tables 3 and 4 . The incidence of $C$. perfringens was $15.13 \%$, with $55.55 \%$ males and $44.44 \%$ females. In the $0-1$ month age group, there were $7.56 \%$, with $61.11 \%$ males and $38.89 \%$ females, and in 
D. D. Singh et al.: Molecular detection of Clostridium perfringens toxinotypes, EPEC, rota- and coronavirus in diarrheic goat kids

the $1-3$ month old group, $7.56 \%$ with $44.44 \%$ males and $55.55 \%$ females. On CLS-BBA, colonies were observed greyish tinged, rounded raised or flat spread, with two zones of hemolysis, and with a clear hemolysis surrounding colony, subsequently enclaved within a concentric partial hemolysis (Fig. 1B). The purity of the culture was assessed by Gram's smear and further confirmed by growth on Egg yolk agar (EYA), with typical opalescence around the growth (Fig. 1C) due to the lecithinase activity of the alpha toxin.

Table 3. Results of positive samples with multiplex PCR for C. perfringens, Real Time PCR for EPEC and osRT-PCR for GARV and BCV and their mixed infection in neonatal goat kids.

\begin{tabular}{|c|c|c|c|c|c|c|c|c|}
\hline \multirow[b]{2}{*}{$\mathrm{N}^{\circ}$} & \multirow[b]{2}{*}{ Pathogen } & \multicolumn{3}{|c|}{$\begin{array}{c}\mathrm{N}^{\circ} \text { of } 0-1 \text { month age } \\
\text { positive samples }\end{array}$} & \multicolumn{3}{|c|}{$\begin{array}{c}\mathrm{N}^{\circ} \text { of } 1-3 \text { month age } \\
\text { positive samples }\end{array}$} & \multirow{2}{*}{\begin{tabular}{|c|} 
Total \\
$\mathrm{N}^{\circ}$ of \\
positive \\
samples
\end{tabular}} \\
\hline & & Male & Female & Total & Male & Female & Total & \\
\hline 1 & C. perfringens & 11 & 7 & 18 & 8 & 10 & 18 & 36 \\
\hline 2 & EPEC & 52 & 44 & 96 & 35 & 31 & 66 & 162 \\
\hline 3 & GARV & 13 & 9 & 22 & 10 & 20 & 30 & 52 \\
\hline 4 & $\mathrm{BCV}$ & 13 & 8 & 21 & 5 & 12 & 17 & 38 \\
\hline 5 & $\begin{array}{l}\text { C. perfringens }+ \\
\text { EPEC }\end{array}$ & 11 & 6 & 17 & 5 & 6 & 11 & 28 \\
\hline 6 & $\begin{array}{l}\text { C. perfringens }+ \\
\text { GARV }\end{array}$ & 3 & 2 & 5 & 1 & 3 & 4 & 9 \\
\hline 7 & $\begin{array}{l}\text { C. perfringens }+ \\
\text { BCV }\end{array}$ & 2 & 1 & 3 & 1 & 1 & 2 & 5 \\
\hline 8 & EPEC + GARV & 11 & 8 & 19 & 9 & 19 & 28 & 47 \\
\hline 9 & $\mathrm{EPEC}+\mathrm{BCV}$ & 10 & 8 & 18 & 4 & 5 & 9 & 27 \\
\hline 10 & GARV+ BCV & 6 & 4 & 10 & 1 & 3 & 4 & 14 \\
\hline 11 & $\begin{array}{l}\text { C. perfringens } \\
+ \text { GARV + BCV }\end{array}$ & 1 & 0 & 1 & 1 & 0 & 1 & 2 \\
\hline 12 & $\begin{array}{l}\text { EPEC + GARV } \\
+ \text { BCV }\end{array}$ & 2 & 4 & 6 & 2 & 2 & 4 & 10 \\
\hline 13 & $\begin{array}{l}\text { C. perfringens }+ \\
\text { EPEC + GARV } \\
+ \text { BCV }\end{array}$ & 0 & 1 & 1 & 1 & 0 & 1 & 2 \\
\hline
\end{tabular}


D. D. Singh et al.: Molecular detection of Clostridium perfringens toxinotypes, EPEC, rota- and coronavirus in diarrheic goat kids

Table 4. Incidence (\%) of $C$. perfringens, EPEC, GARV and BCV and their mixed infection in neonates

\begin{tabular}{|c|c|c|c|c|c|c|c|c|}
\hline \multirow[b]{2}{*}{$\mathrm{N}^{\circ}$} & \multirow[b]{2}{*}{ Pathogen } & \multicolumn{3}{|c|}{$\begin{array}{l}\text { In } 0-1 \text { month age } \\
\text { incidence }(\%)\end{array}$} & \multicolumn{3}{|c|}{$\begin{array}{c}\text { In } 1-3 \text { months age } \\
\text { incidence }(\%)\end{array}$} & \multirow{2}{*}{$\begin{array}{c}\text { Total } \\
\text { incidence } \\
(\%)\end{array}$} \\
\hline & & Male & Female & Total & Male & Female & Total & \\
\hline 1 & C. perfringens & 4.62 & 2.94 & 7.56 & 3.36 & 4.20 & 7.56 & 15.13 \\
\hline 2 & EPEC & 21.85 & 18.49 & 40.34 & 14.71 & 13.02 & 27.73 & 68.07 \\
\hline 3 & GARV & 5.46 & 3.78 & 9.24 & 4.20 & 8.40 & 12.60 & 21.85 \\
\hline 4 & $\mathrm{BCV}$ & 5.46 & 3.78 & 8.82 & 2.10 & 5.04 & 7.14 & 15.97 \\
\hline 5 & $\begin{array}{l}\text { C. perfrigens + } \\
\text { EPEC }\end{array}$ & 4.62 & 2.52 & 7.14 & 2.1 & 2.52 & 4.62 & 11.76 \\
\hline 6 & $\begin{array}{l}\text { C. perfringens } \\
+ \text { GARV }\end{array}$ & 1.26 & 0.84 & 2.1 & 0.42 & 1.26 & 1.68 & 3.78 \\
\hline 7 & $\begin{array}{l}\text { C. perfringens } \\
+\mathrm{BCV}\end{array}$ & 0.84 & 0.42 & 1.26 & 0.42 & 0.42 & 0.84 & 2.10 \\
\hline 8 & $\begin{array}{l}\text { EPEC } \\
+ \text { GARV }\end{array}$ & 4.62 & 3.36 & 7.98 & 3.78 & 7.98 & 11.76 & 19.74 \\
\hline 9 & $\mathrm{EPEC}+\mathrm{BCV}$ & 4.20 & 3.36 & 7.56 & 1.68 & 2.10 & 3.78 & 11.34 \\
\hline 10 & GARV+BCV & 2.52 & 1.68 & 4.20 & 0.42 & 1.26 & 1.68 & 5.88 \\
\hline 11 & $\begin{array}{l}\text { C. perfringens } \\
+ \text { GARV+BCV }\end{array}$ & 0 & 0.42 & 0.42 & 0 & 0.42 & 0.42 & 0.84 \\
\hline 12 & $\begin{array}{l}\text { EPEC + } \\
\text { GARV + BCV }\end{array}$ & 0.84 & 1.68 & 2.52 & 0.84 & 0.84 & 1.68 & 4.20 \\
\hline 13 & $\begin{array}{l}\text { C. perfringens } \\
\text { + EPEC + } \\
\text { GARV + BCV }\end{array}$ & 0 & 0.42 & 0.42 & 0.42 & 0 & 0.42 & 0.84 \\
\hline
\end{tabular}

From all 36 positive cultures, DNA was extracted and toxinotyping multiplex PCR (TmPCR) was done (Table 5). In positive fecal samples, 75\% were $C$. perfringens toxinotype A and $25 \%$ C. perfringens toxinotype D (Fig. 2A). Among the detected 'A' toxinotypes, $37.04 \%$ were $0-1$ month of age and $62.96 \% 1-3$ months of age. The gene encoding $\beta 2$-toxin was present in $61.11 \%$ isolates toxinotyped with 15 in the $0-1$ month group and 7 in the 1-3 month age group.

Isolation, molecular detection and incidence of EPEC. Of the fecal swabs collected from 238 clinically diarrheic kids, 162 isolates were obtained which showed lactose fermenting colonies confirmed by re-inoculation on EMB agar for metallic sheen. To screen these isolates for enteropathogenic property, $b f p A$ gene based SYBR-green real time PCR with melt-curve analysis was done (Fig. 3). The SYBR-green real time assay for $b f p \mathrm{~A}$ gene based screening of EPEC has a sensitivity with limit of detection (LOD) up to $3 \times 10^{\circ} \mathrm{CFU} / \mathrm{mL}$ and a specificity of 99 per cent when compared with non-EPEC 
D. D. Singh et al.: Molecular detection of Clostridium perfringens toxinotypes, EPEC, rota- and coronavirus in diarrheic goat kids

strains and other gram negative bacteria (unpublished data). The incidence of EPEC in the clinically affected kids was $68.07 \%$, with $40.34 \%$ in the $0-1$ month age group and $27.73 \%$ in the $1-3$ month age group (Tables 3 and 4 ).

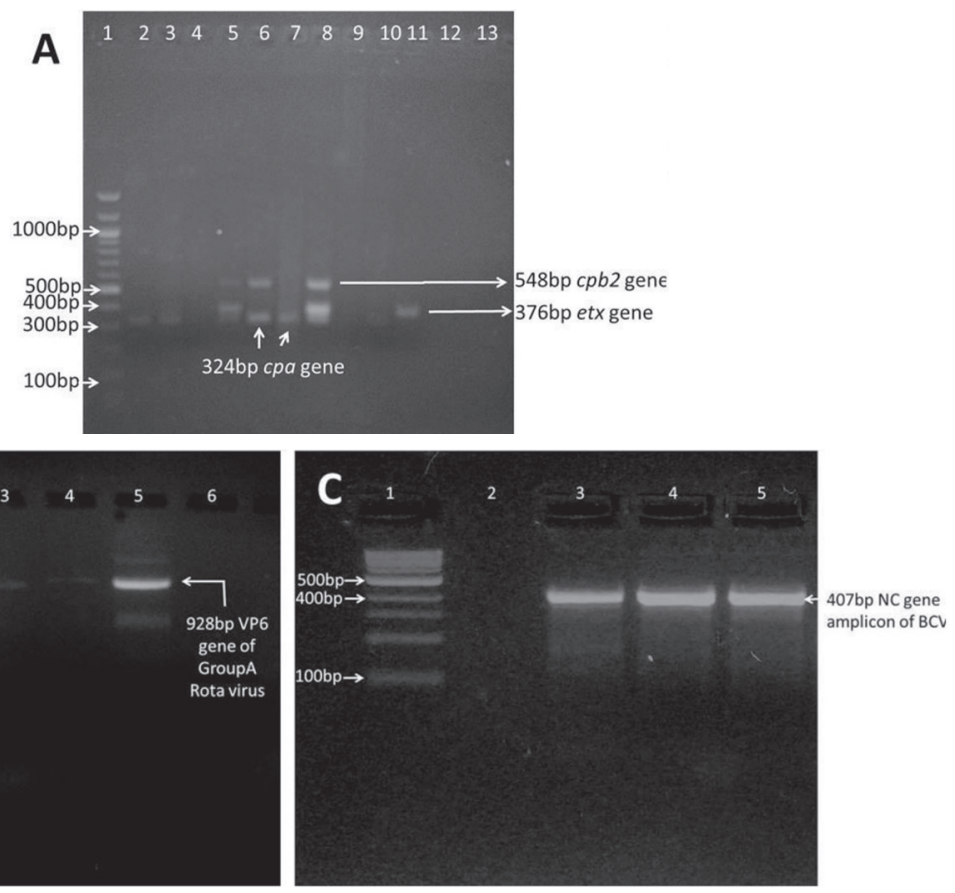

Fig. 2. PCR detection of various enteric pathogens. (A) Gel picture of TmPCR showing cpa, etx and $c p b 2$; (B) osRT-PCR showing amplification of VP6 gene of GARV; (C) osRT-PCR showing amplification of Nucleocapsid gene of BCV.

Table 5. Results of multiplex PCR toxinotypes of C. perfringens in neonatal goat kids

\begin{tabular}{|c|c|c|c|c|c|c|c|}
\hline \multirow[b]{2}{*}{$\mathrm{N}^{\circ}$} & \multirow[b]{2}{*}{ Toxin gene } & \multirow[b]{2}{*}{ Toxinotypes } & \multicolumn{2}{|c|}{$\begin{array}{c}\mathrm{N}^{\circ} \text { of isolates from } 0-1 \\
\text { month age kids }\end{array}$} & \multicolumn{2}{|c|}{$\begin{array}{c}\mathrm{N}^{\circ} \text { of isolates from 1-3 } \\
\text { months age kids }\end{array}$} & \multirow[t]{2}{*}{$\begin{array}{l}\text { Total } \mathrm{N}^{\circ} \\
\text { of isolates }\end{array}$} \\
\hline & & & Male & Female & Male & Female & \\
\hline 1 & cpa & A & 05 & 05 & 9 & 8 & 27 \\
\hline 2 & etx & $\mathrm{D}$ & 1 & 3 & 2 & 3 & 9 \\
\hline 3 & $c p b 2$ & $\begin{array}{l}\mathrm{A}, \mathrm{B}, \mathrm{C}, \mathrm{D} \\
\text { and } \mathrm{E}\end{array}$ & 10 & 5 & 4 & 3 & 22 \\
\hline
\end{tabular}


D. D. Singh et al.: Molecular detection of Clostridium perfringens toxinotypes, EPEC, rota- and coronavirus in diarrheic goat kids

Incidence of GARV and BCV by osRT-PCR. Based on VP6 gene based osRT-PCR, $21.85 \%$ were found positive for GARV (Fig. 2B), with $9.24 \%$ in the $0-1$ month age group and $12.60 \%$ in the $1-3$ month age group. The non-denatured RNA samples, amplified through Nucleocapsid gene based osRT-PCR, detected $15.97 \%$ positive for BCV (Fig. $2 \mathrm{C}$; Tables 3 and 4 ) with $8.82 \%$ in the $0-1$ month age group and $7.14 \%$ in $1-3$ month old kids.
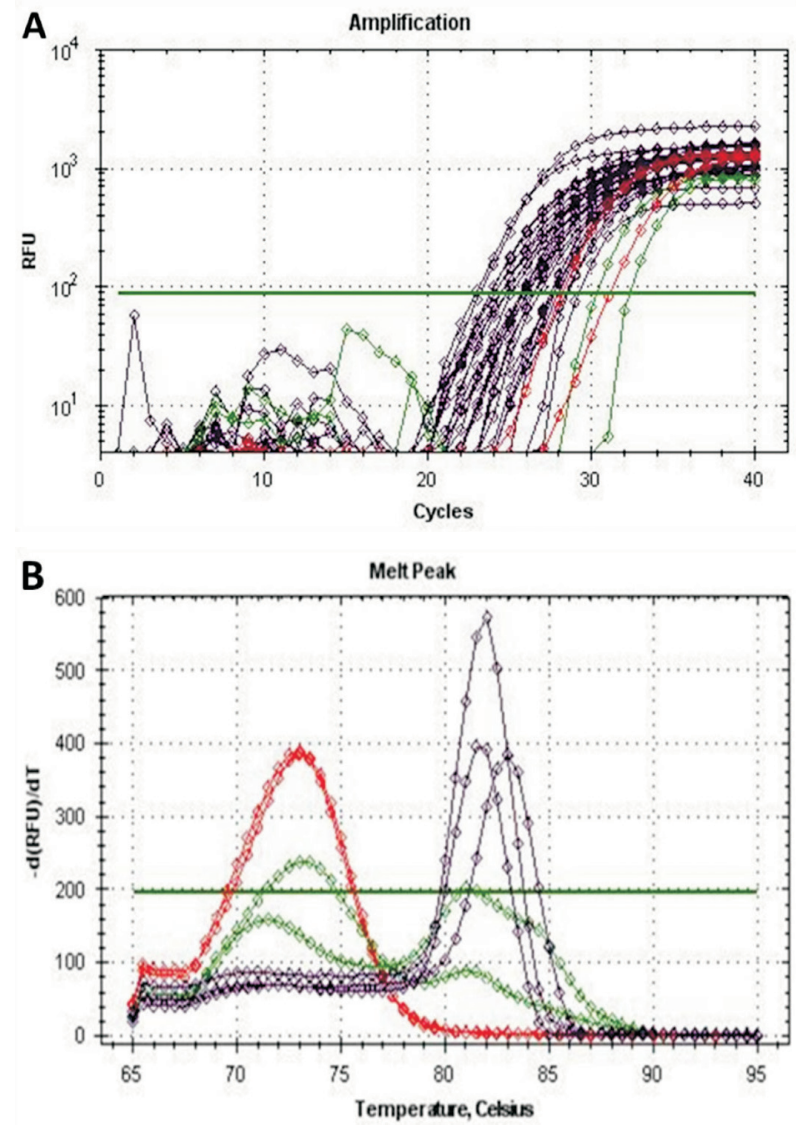

Fig. 3. SYBR green chemistry based Real time PCR assay of $b f p$ A gene for screening EPEC. (A) $\mathrm{Cq}$ (cycle quantification) or cycle threshold $(\mathrm{Ct})$ of Positive control (purple), Negative control (Red) and No template control (Green). (B) Melting peak of approximately $85^{\circ} \mathrm{C}$ (purple) above the threshold 150 are positive amplicons. Whereas the other noisy peaks less than $85^{\circ} \mathrm{C}$ and threshold line are primer dimers. 
Incidence of mixed infection. The results of mixed infection incidence are presented in Tables 3 and 4. Mixed infections in the clinically diarrheic kids were found to be $11.76 \%$ positive for $C$. perfringens and EPEC with $7.14 \%$ in the $0-1$ month age group and $4.62 \%$ in the 1-3 month age group. Further, 3.78\% samples were positive for $C$. perfringens and GARV and among them $55.55 \%$ were $0-1$ month old and $44.44 \%$ were $1-3$ months of age. The combination including EPEC and GARV showed 19.74\% incidence of mixed infection including $7.98 \%$ kids of $0-1$ month of age and $11.76 \%$ kids of $1-3$ months of age. EPEC infection along with BCV was seen in $11.34 \%$ cases of diarrhea. Another combination including $C$. perfringens and BCV was detected in $2.1 \%$ samples, with $60 \%$ at $0-1$ month of age and 40\% 1-3 months of age. Mixed infection of GARV and BCV was found in 5.88\% with $71.43 \%$ 0-1 month of age and $28.57 \%$ kids $1-3$ months of age. In all, the incidence rate of EPEC, GARV and BCV was $4.20 \%$. Only $0.84 \%$ samples were positive for mixed infection with $C$. perfringens, GARV and BCV; and the same proportion of incidence was observed for $C$. perfringens, EPEC, GARV and BCV.

\section{Discussion}

Neonatal infectious pathologies in goats may be caused by bacteria, viruses, parasites or nutritional deficiencies, often in synergy and usually characterized by high morbidity and mortality. Rotaviruses, Coronaviruses and bacteria, such as Escherichia coli, Salmonella spp. and Clostridium spp., are etiological agents more commonly involved in gastro-enteric diseases in kids. In our study, 238 neonatal diarrheic goat kids were studied, of which $47.48 \%$ were $0-1$ month old and 52.52\% 1-3 months of age.

Clostridium perfringens is an important cause of enteric disease in humans and domestic animals. In particular, $C$. perfringens is responsible for several forms of enterotoxaemia, which differs in clinical manifestation and severity according to the toxigenic type involved and specific toxins produced (SONGER, 1996; SUMITHRA et al., 2013). In the present study, the prevalence of $C$. perfringens was $15.13 \%$ with $7.56 \%$ occurrence in each age group, viz., 0-1 and 1-3 months age. The bacteria produce several toxins which play key roles in the pathogenesis of the disease (SONGER, 1996) and are classified into five toxinotypes (A, B, C, D, and E) according to the production of 4 major toxins, namely alpha (CPA), beta (CPB), epsilon (ETX), and iota (ITX) (NIILO, 1980; UZAL and SONGER, 2008; UZAL et al., 2010). However, C. perfringens are able to produce up to 15 toxins in various combinations, including lethal toxins such as perfringolysin ' $\mathrm{O}$ ' (PFO), enterotoxin (CPE), and $\beta 2$ toxin (CPB2) (GARMORY et al., 2000; UZAL et al., 2010)

All C. perfringens strains isolated in the study produced $\alpha$ (27) and $\varepsilon$-toxin (9), cultural characteristics including double zones of hemolysis on CLS-BBA, and lecithinase activity on EYA as reported by GRECO et al. (2005). An inner, complete zone 
of hemolysis is caused by PFO and the less complete outer zone is caused by CPA(UZAL and SONGER, 2008). On microscopic examination of smears, C. perfringens appeared as stumpy or slender gram positive rods with either truncated or plumby ends, as seen by earlier researchers (UZAL and SONGER, 2008).

In the current study, 22 samples showed positive for $\beta 2$ toxin. As a major toxigenic factor in various isolates of $C$. perfringens, the $\beta 2$ toxin could be considered as highly virulent due to its association with severe clinical diarrhea (GIBERT et al., 1997; MANTECA et al., 2002; VAN ASTEN et al., 2010). It is also important that the association of $C$. perfringens type A is not clearly understood, although some studies have reported fatal hemolytic disease in lambs and associated gas-gangrene lesions in adult sheep (NIILO, 1986; SONGER, 1996), and enteritis in calves (SAVIC et al., 2012). Contact with spores in the vicinity adds to the risk of disease further predisposing induction of enterotoxaemia caused by various toxinotypes of $C$. perfringens, due to a change in the conditions of the gut micro-environment. Based on the findings of the current study, $C$. perfringens types $\mathrm{A}$ and $\mathrm{D}$ are found to be common causes of enterotoxemia in neonatal goat kids, which corroborates with the results and findings of GRECO et al. (2005), where young lambs and kids were investigated in southern Italy, and a similar report in an earlier investigation (MIYASHIRO et al., 2007), where 18 month old goats were affected by toxinotypes A and D.

From 15 samples, $C$. perfringens types A and D showed potential to produce $\beta 2$ toxin, as revealed by amplification of the $c p b 2$ gene. The major role of the $\beta 2$ toxin in causing clinical diarrhea and other associated pathogenesis caused due to enterotoxaemia is not very evident, but at the same time, a strong relationship exists between the toxin and the disease (GRECO et al., 2005). There are other reports that relate the pathogenicity of cpb2 expressing C. perfringens with clinical diarrhea in neonates, where piglets showed severe diarrhea, which indicates the fact that $\beta 2$ toxin plays a larger role in neonatal diarrhea (WATERS et al., 2003). There are reports of $\beta 2$ toxin producing $C$. perfringens associated with caprine enterotoxaemia (DRAY, 2004; UZAL et al., 2008) in subclinical necrotic enteritis in laying hens (ALLAART et al., 2012), Hemorrhagic bowel syndrome (HUS) or enterotoxaemia in bovines (DENNISON et al., 2005; LEBRUN et al., 2007; FERRAREZI et al., 2008) and being involved in typhlocolitis or enterocolitis in equines (VILEI et al., 2005; TIMONEY et al., 2005)

C. perfringens type $\mathrm{D}$, that harbours the genes cpa ( $\alpha$ toxin) and etx ( $\varepsilon$ toxin), was isolated from 9 samples during our survey. In previous instances, the association has been already reported of $C$. perfringens type $\mathrm{D}$ with clinical cases of enterotoxemia in goats (FERNANDEZ-MIYAKAWA and UZAL, 2003; GRECO et al., 2005; MIYASHIRO et al., 2007). 
Enteropathogenic Escherichia coli (EPEC) are an important cause of infantile diarrhea in developing countries (NATARO and KAPER, 1998; BUGAREL et al., 2011). EPEC colonizes the small intestinal epithelial lining, leading to 'attaching and effacing' (A/E) lesions in the microvilli, characterized by intimate aggregation and attachment of bacteria (KNUTTON et al., 1989; ALLEN-VERCOE et al., 2006). There are several different well-characterized and putative adhesive factors involved in this process including BFP, and there is a set of defined $b f p A$ mutants and transformants supporting the role of BFP (CLEARY et al., 2004).

Here, we report a standardized SYBR Green chemistry based real time PCR protocol for differentiation of EPEC and non-EPEC isolates (target organisms responsible for diarrhea) in neonatal goat kids using the $b f p \mathrm{~A}$ gene following melt-curve analysis. In the present study the incidence of EPEC was $68.08 \%$ in neonatal diarrheic kids, with $40.34 \%$ at $0-1$ month of age which is higher than the earlier findings of WANI et al. (2004), who reported $26.6 \%$ incidence of EPEC, whereas the findings of BHAT et al. (2008) portrayed a much lower prevalence of $12.5 \%$ EPEC in diarrheic lambs. The variations in the prevalence of EPEC could be attributed to geo-climatological, seasonal, host-species determinants etc. However, prevalence studies should be done by continuous surveillance mechanisms to project the closer-to-reality data.

Diarrheagenic E. coli strains were among the first pathogens for which molecular diagnostic methods were developed. PCR-based methods are more sensitive and rapid than phenotypic tests performed on individual colonies (RICH et al., 2001). Among the several chemistries available for real-time PCR assays, SYBR Green based assays are the most widely used. Previously, real-time PCR based methods have been reported for detection of many pathogens of veterinary importance (AGUERO et al., 2007). SYBR green based real time PCR assay was used earlier to differentiate EPEC, Verotoxic E. coli and other enteroaggregative $E$. coli, and it was concluded in that study that it may be used as an effective diagnostic tool compared to conventional PCR, for detection of $E$. coli strains (BISCHOFF et al., 2005; GUION et al., 2008)

Rotavirus is responsible for causing economically significant maladies in neonates of many domestic animals (KAPIKIAN and CHANOCK, 1996; ESTES and KAPIKIAN, 2007). In ovines, rotaviruses are known to cause enteritis and diarrhea (WANI et al., 2004; GAZAL et al., 2011). In the present study, a much higher proportion, viz., $21.85 \%$ diarrheic neonatal goat kid samples were positive for rotaviruses, with $9.24 \%$ falling in the $0-1$ month age group and $12.60 \%$ in the $1-3$ month age group. This occurrence is contrary to DEY et al. (2007) who reported rotavirus in $8.68 \%$ diarrheic fecal specimens in Black Bengal Goats, which is lower than our findings. Kids in a 7 day to 1-month age group were reported (DEY et al., 2007) to be most frequently found with rotavirus infection (13.63\%). GARV in the present study was detected in $21.85 \%$ samples, which 
was more than the findings of DEY et al. (2007). KHAFAGI et al. (2010) determined the prevalence of rotavirus associated with diarrhea in lambs and kids in $12.3 \%$ samples. WANI et al. (2004) recorded GARV association with lamb diarrhea in an outbreak in Kashmir, India, in 25\% diarrheic lambs. Most of the studies assessed the relevance of $\mathrm{BCV}$ as the primary pathogen in neonatal calf diarrhea (NCD) and the associated mortality (AMMAR et al., 2014). In the present study, the incidence of BCV was $15.95 \%$ with a slightly higher incidence $(8.82 \%)$ in the $0-1$ month group than the $1-3$ month old (7.14\%) kids. A previously reported prevalence for BCV was $11.76 \%$ from clinical diarrheic calves aged below 3 months (RAI et al., 2011). A prevalence rate of 3-20\% has been recorded for coronavirus in calf diarrhea (MAYAMEEI et al., 2009).

In the present study mixed infections of various enteric pathogens were studied to identify their synergistic role in causing neonatal diarrhea and mortality in goat kids. The most common combination was EPEC and GARV, with an incidence of $19.74 \%$; $C$. perfringens plus EPEC with $11.76 \%$ and EPEC with BCV was $11.34 \%$, indicating the role of mixed infection in neonatal diarrhea.

The occurrence of GARV and BCV mixed infection was 5.88\%. C. perfringens and GARV revealed occurrence of $3.78 \%$, and $C$. perfringens and BCV mixed infection was detected in $2.1 \%$ of cases. However, interestingly, the three pathogens studied, viz., $C$. perfringens, GARV, BCV and all four pathogens i.e. C. perfringens, EPEC, GARV and BCV were detected in only $0.84 \%$ fecal samples. As no such study has been conducted previously in neonatal goat kids no literature could be traced for comparative studies. However, BOK et al. (2015) detected a high percentage of samples (34.79\%) infected with both BCV and GARV in calves. This was somewhat expected, as GARV is responsible for the majority of neonatal calf diarrhea worldwide (KAPIKIAN and CHANOCK, 1996). The findings of AMMAR et al. (2014) showed a prevalence of GARV and BCV infection at $14.63 \%$ and $20.73 \%$, respectively.

\section{Conclusion}

The present study looks at the occurrence of enteric diseases, which are a major cause of mortality in neonatal kids under field conditions. Neonatal enteritis is caused by a battery of etiological agents, with incidences of mixed infections, which complement each other while exacerbating ill-health due to an imbalance in immunity. A multiplex PCR technique aided the characterization of $C$. perfringens toxinotypes; viral etiologies such as GARV and BCV could be detected using a quick and sensitive osRT-PCR, where isolation studies and serological studies would be difficult. The detection of EPEC isolates acts as an indicator for the presence of virulent $E$. coli in the herd, which was detected by $b f p A$ gene based SYBR green real time PCR. There is a considerable influence of age on the incidence of EPEC, as evidenced by the higher percentages in the 0 -1month age 
D. D. Singh et al.: Molecular detection of Clostridium perfringens toxinotypes, EPEC, rota- and coronavirus in diarrheic goat kids

group compared to the kids 1-3 months of age. Gender did not have any impact on the disease incidence in either age group. In general, molecular tests are fast, accurate, and less laborious compared to the conventional methods of diagnosis, including isolation and culture techniques. Early diagnosis will help in treatment and in devising a kid-cum-dam hood vaccination for healthy neonates, to protect them, which will eventually prevent the economic losses to the farmers.

\section{Acknowledgements}

The authors are thankful to the Director, ICAR-CIRG, Makhdoom, Mathura for carrying out the research work at ICAR-CIRG; The Dean, COVSc and Dean, PGS, DUVASU, Mathura, UP, India for providing the necessary facilities to carry out the work. The authors are also thankful to CABin Network Project (ICAR-IASRI, New Delhi) for providing financial support to carry out the research work.

\#Part of PhD thesis submitted to College of Veterinary Sciences, DUVASU, Mathura, Uttar Pradesh, India

\section{References}

AGUERO, M., E. SAN MIGUEL, A. SANCHEZ, C. GOMEZ-TEJEDOR, M. A. JIMENEZCLAVERO (2007): A fully automated procedure for the high throughput detection of avian influenza virus by real-time reverse transcription-polymerase chain reaction. Avian Dis. 51, 235-241.

ALLAART, J. G., N. D. DE BRUIJN, A. J. VAN ASTEN, T. H. FABRI, A. GRÖNE (2012): NetBproducing and beta2-producing Clostridium perfringens associated with subclinical necrotic enteritis in laying hens in the Netherlands. Avian Pathol. 41. 541-546.

ALLEN-VERCOE, E., B. WADDELL, M. C. TOH, R. DEVINNEY (2006): Amino acid residues within enterohemorrhagic Escherichia coli O157:H7 Tir involved in phosphorylation, alphaactinin recruitment, and Nck-independent pedestal formation. Infect. Immun. 74, 6196-6205.

AMMAR, S. S., K. MOKHTARIA, B. B. TAHAR, A. A. AMAR, B. A. REDHA, B. YUVA, H. S. MOHAMED, N. ABDELLATIF, B. LAID (2014): Prevalence of rotavirus (GARV) and coronavirus $(\mathrm{BCoV})$ associated with neonatal diarrhea in calves in western Algeria. Asian Pac. J. Trop. Biomed. 4, S318-S322.

ANDRÉS, S., A. JIMÉNEZ, J. SÁNCHEZ, J. M. ALONSO, L. GÓMEZ, F. LÓPEZ, J. REY (2007): Evaluation of some etiological factors predisposing to diarrhoea in lambs in "La Serena" (Southwest Spain). Small Rumin. Res. 70, 272-275.

BHAT, M. A., Y. NISHIKAWA, S. A. WANI (2008): Prevalence and virulence gene profiles of Shiga toxin-producing Escherichia coli and enteropathogenic Escherichia coli from diarrhoeic and healthy lambs in India. Small Rumin. Res. 75, 65-70.

BISCHOFF, C., J. LÜTHY, M. ALTWEGG, F. BAGGI (2005): Rapid detection of diarrheagenic $E$. coli by real-time PCR. J. Microbial. Met. 61, 335-341.

BOK, M., S. MIÑO, D. RODRIGUEZ, A. BADARACCO, I. NUÑES, S. P. SOUZA, G. BILBAO, G., E. L. URIARTE, R. GALARZA, C. VEGA, A. ODEON (2015): Molecular and antigenic

Vet. arhiv 88 (1), 1-20, 2018 
D. D. Singh et al.: Molecular detection of Clostridium perfringens toxinotypes, EPEC, rota- and coronavirus in diarrheic goat kids

characterization of bovine Coronavirus circulating in Argentinean cattle during 1994-2010. Vet. Microbiol. 181, 221-229.

BUGAREL, M., A. MARTIN, P. FACH, L. BEUTIN (2011): Virulence gene profiling of enterohemorrhagic (EHEC) and enteropathogenic (EPEC) Escherichia coli strains: a basis for molecular risk assessment of typical and atypical EPEC strains. BMC Microbiology, DOI: $10.1186 / 1471-2180-11-142$

CHARTIER, C., C. PARAUD (2012): Coccidiosis due to Eimeria in sheep and goats, a review. Small Rumin. Res. 103, 84-92.

CLARK, M. A. (1993): Bovine coronavirus. Br. Vet. J. 149, 51-70.

CLEARY, J., L. LAI, R. K. SHAW, A. S. IWANOWSKA, M. S. DONNENBERG, G. FRANKEL, S. KNUTTON (2004): Enteropathogenic Escherichia coli (EPEC) adhesion to intestinal epithelial cells: role of bundle-forming pili (BFP), EspA filaments and intimin. Microbiol. $150,527-538$.

CROXEN, M. A., B. B. FINLAY (2010): Molecular mechanisms of Escherichia coli pathogenicity. Nature Rev. Microbiol. 8, 26-38.

DENNISON A. C., D. C. VAN METRE, P. S. MORLEY, R. J. CALLAN, E. C. PLAMPIN, R. P. ELLIS (2005): Comparison of the odds of isolation, genotypes, and in vivo production of major toxins by Clostridium perfringens obtained from the gastrointestinal tract of dairy cows with hemorrhagic bowel syndrome or left-displaced abomasum. J. Am. Vet. Med. Assoc. 227, 132-138.

DEY, B. K., M. S. AHMED, M. U. AHMED (2007): Rota viral diarrhea in kids of black Bengal goats in Mymensingh. Bangladesh J. Vet. Med. 5, 59-62.

DONNENBERG, M. S., J. B. KAPER (1992): Enteropathogenic Escherichia coli. Infect. Immun. 60, 3953-3961.

DRAY, T., (2004): Clostridium perfringens type A and beta2 toxin associated with enterotoxemia in a 5-week-old goat. Can. Vet. J. 45, 251-253.

ESTES, M. K., A. Z. KAPIKIAN (2007): Rotaviruses. In: Fields Virology, (Knipe, D. M., P. M. Howley, D. E. Griffin, R. A. Lamb, M. A. Martin, B. Roizman, S. E. Straus, Eds.). $5^{\text {th }}$ ed., Vol. 2. Lippincott Williams \& Wilkins/ Wolters Kluwer, Philadelphia, pp. 1917-1974.

FERNANDEZ-MIYAKAWA, M. E., F. A. UZAL (2003): The early effects of Clostridium perfringens type D epsilon toxin in ligated intestinal loops of goats and sheep. Vet. Res. Commun. 27, 231-241.

FERRAREZI, M. C., T. C. CARDOSO, I. S. DUTRA (2008): Genotyping of Clostridium perfringens isolated from calves with neonatal diarrhea. Anaerobe 14, 328-331.

GARMORY, H. S., N. CHANTER, N. P. FRENCH (2000): Occurrence of Clostridium perfringens beta2-toxin amongst animals, determined using genotyping and subtyping PCR assays. Epidemiol. Infect. 124, 61-67.

GAZAL, S., I. A. MIR, A. IQBAL, A. K. TAKU, B. KUMAR, M. A. BHAT (2011): Ovine rotaviruses. Open Vet. J. 1, 50-54. 
D. D. Singh et al.: Molecular detection of Clostridium perfringens toxinotypes, EPEC, rota- and coronavirus in diarrheic goat kids

GIBERT, M., C. JOLIVET-RENAUD, M. R. POPOFF (1997): Beta2 toxin, a novel toxin produced by Clostridium perfringens. Gene 203, 65-73.

GIRON, J. A., A. S. Y. HO, G. K. SCHOOLNIK (1991): An inducible bundle forming pilus of Enteropathogenic Escherichia coli. Science 254, 710-714.

GRECO, G., A. MADIO, D. BUONAVOGLIA, M. TOTARO, M. CORRENTE, V. MARTELLA, C. BUONAVOGLIA (2005): Clostridium perfringens toxin-types in lambs and kids affected with gastroenteric pathologies in Italy. Vet. J. 170, 346-350.

GUION, C. E., T. J. OCHOA, C. M. WALKER, F. BARLETTA, T. G. CLEARY (2008): Detection of Diarrheagenic Escherichia coli by Use of Melting-Curve analysis and Real-Time Multiplex PCR. J. Clin. Microbiol. 46, 1752-1757.

HABEEB, A. F. S. A. (1969): Studies on $\varepsilon$-prototoxin of Clostridium perfringens type D. 1. Purification methods: evidence for multiple forms of $\varepsilon$-prototoxin. Archiv. Biochem. Biophys. 130, 430-440.

HALL, T. (1999): BioEdit: a user-friendly biological sequence alignment editor and analysis program for Windows 95/98/ NT. Nucleic Acids Symp. Ser. 41, 95-98.

HUOCHUN, Y., D. NIANXING, X. WEIYAN (1990): Seroepizootiological survey of bovine coronavirus in cattle, human and other animals. Journal of Nanjing Agricultural University (China).

KAPER, J. B., J. P. NATARO, H. L. MOBLEY (2004): Pathogenic Escherichia coli. Nature Rev. Microbiol. 2, 123-140

KAPIKIAN, A. Z., R. M. CHANOCK (1996): Rotaviruses. In: Fields Virology, (Fields, B. N., D. M. Knipe, P. M. Howley, R. M. Chanock, J. L. Melinick, T. P. Monath, B. Roizman, S. E. Straus, Eds.) $3^{\text {rd }}$ ed., Vol. 2. Lippincott-Raven, Philadelphia, pp. 1657-1707.

KHAFAGI, M. H., M. A. MAHMOUD, A. R. HABASHI (2010): Prevalence of rotavirus infections in small ruminants. Global Veterinaria 4, 539-543.

KNUTTON, S., T. BALDWIN, P. H. WILLIAMS, A. S. MCNEISH (1989): Actin accumulation at sites of bacterial adhesion to tissue culture cells: basis of a new diagnostic test for enteropathogenic and enterohemorrhagic Escherichia coli. Infect. Immun. 57, 1290-1298.

LEBRUN, M., P. FILEE, B. MOUSSET, D. DESMECHT, M. GALLENI, J. G. MAINIL, A. LINDEN (2007): The expression of Clostridium perfringens consensus beta2 toxin is associated with bovine enterotoxaemia syndrome. Vet. Microbiol. 120, 151-157.

MANTECA, C., G. DAUBE, T. JAUNIAUX, A. LINDEN, V. PIRSON, J. DETILlEUX, A. GINTER, P. COPPE, A. KAECKENBEECK, J. G. MAINIL (2002): A role for the Clostridium perfringens $\beta 2$ toxin in bovine enterotoxaemia? Vet. Microbiol. 86, 191-202.

McClANE, B. A., F. A. UZAL, M. F. MIYAKAWA, D. LYERLY, T. WILKINS (2005): The enterotoxic Clostridia. In: The Prokaryotes: An Evolving Electronic Resource for the Microbiological Community, (Dworkin, M., S. Falkow, E. Rosenberg, K. H. Schleifer, E. Stackebrandt, Eds.), Vol. 4. Springer-Verlag, New York, pp. 698-752.

MATTHIJNSSENS, J., M. RAHMAN, M. VAN RANST (2008): Two out of the 11 genes of an unusual human G6P[6] rotavirus isolate are of bovine origin. J. Gen. Virol. 89, 2630-2635.

Vet. arhiv 88 (1), 1-20, 2018 
D. D. Singh et al.: Molecular detection of Clostridium perfringens toxinotypes, EPEC, rota- and coronavirus in diarrheic goat kids

MAYAMEEI, A., G. MOHAMMADI, S. YAVARI, E. AFSHARI, A. OMIDI (2009): Evaluation of relationship between Rotavirus and Coronavirus infections with calf diarrhoea by capture ELISA. Comp. Clin. Pathol. 19, 553-557.

MEBUS, C. A., E. L. STAIR, M. B. RHODES, M. J. TWIEHAUS (1973): Neonatal calf diarrhea: propagation, attenuation, and characteristics of a coronavirus-like agent. Am. J. Vet. Res. 34, 145-150.

MIYASHIRO, S., A. F. C. NASSAR, C. DEL FAVA, A. D. CABRAL, M. SILVA(2007): Clostridium perfringens types A and D associated with enterotoxemia in an 18-month-old goat. J. Venom. Anim. Toxins Incl. Trop. Dis. 13, 885-893.

MUÑOZ, M., M. ALVAREZ, I. LANZA, P. CARMENES (1996): Role of enteric pathogens in the aetiology of neonatal diarrhoea in lambs and goat kids in Spain. Epidemiol. Infect. 117, 203-211.

NATARO, J. P., J. B. KAPER (1998): Diarrheagenic Escherichia coli. Clin. Microbiol. Rev. 11, 142-201.

NIILO, L. (1980): Clostridium perfringens in animal disease: a review of current knowledge. Can. Vet. J. 21, 141-148.

NIILO, L. (1986): Enterotoxemic Clostridium perfringens. In: Pathogenesis of Bacterial Infections in Animals (Gyles, C. L., C. O. Thoen, Eds.), Iowa State University Press, Ames, pp. 80-86.

OZMEN, O., A. YUKARI, M. HALIGUR, S. SAHINDURAN (2006): Observations and immunohistochemical detection of Coronavirus, Cryptosporidium parvum and Giardia intestinalis in neonatal diarrhoea in lambs and kids. Schweiz. Arch. Tierheilkd. 148, 357-364.

PAPP, H., B. LÁSZLÓ, F. JAKAB, B. GANESH, S. DE GRAZIA, J. MATTHIJNSSENS, M. CIARLET, V. MARTELLA, K. BÁNYAI (2013): Review of group A rotavirus strains reported in swine and cattle. Vet. Microbiol. 165, 190-199.

PAWAIYA, R. V. S., D. D. SINGH, N. K. GANGWAR, K. GURURAJ, V. KUMAR, S. PAUL, N. SHARMA, A. K. MISHRA, A. KUMAR, D. K. SHARMA, S. V. SINGH (2017): Retrospective study on mortality of goats due to alimentary system diseases in an organized farm. Small Rumin. Res. 149, 141-146.

RAI, R. B., A. HANSHA, S. RAI, B. SINGH, H. KUMAR, A. K. SINGH, T. DAMODARAN, K. DHAMA (2011): Prevalence of rota and coronavirus infections in calves of Barabanki and Raebareli districts of U.P. Indian J. Vet. Pathol. 35, 73-74.

RICH, C., A. ALFIDJA, J. SIROT, B. JOLY, C. FORESTIER (2001): Identification of human enterovirulent Escherichia coli strains by multiplex PCR. J. Clin. Lab. Anal. 15, 100-103.

SAVIC, B., R. PRODANOVIC, V. IVETIC, O. RADANOVIC, J. BOJKOVSKI (2012): Enteritis associated with Clostridium perfringens type A in 9-month-old calves. Can. Vet. J. 53, 174.

SAYEED, S., M. E. FERNANDEZ-MIYAKAWA, D. J. FISHER, V. ADAMS, R. POON, J. I. ROOD, F. A. UZAL, B. A. McCLANE (2005): Epsilon-toxin is required for most Clostridium perfringens type $\mathrm{D}$ vegetative culture supernatants to cause lethality in the mouse intravenous injection model. Infect. Immun. 73, 7413-7421. 
D. D. Singh et al.: Molecular detection of Clostridium perfringens toxinotypes, EPEC, rota- and coronavirus in diarrheic goat kids

SONGER, J. G. (1996): Clostridial enteric diseases of domestic animals. Clin. Microbiol. Rev. 9, 216-234.

SUMITHRA, T. G., V. K. CHATURVEDI, S. J. SIJU, C. SUSAN, M. RAWAT, A. K. RAI, S. C. SUNITA (2013): Enterotoxaemia in goats - A review of current knowledge. Small Rumin. Res. $114,1-9$.

TIMONEY, J. F., M. HARTMANN, L. FALLON, E. FALLON, J. WALKER (2005): Antibody responses of mares to prepartum vaccination with Clostridium perfringens bacterin and $\beta 2$ toxin. Vet. Rec. 157, 810-812.

TSUNEMITSU, H., D. R. SMITH, L. J. SAIF (1999). Experimental inoculation of adult dairy cows with bovine coronavirus and detection of coronavirus in feces by RT-PCR. Arch. Virol. 144, 167-175.

UZAL, F. A., J. G. SONGER (2008): Diagnosis of Clostridium perfringens intestinal infections in sheep and goats. J. Vet. Diagn. Invest. 20, 253-265.

UZAL, F. A., D. J. FISHER, J. SAPUTO, S. SAYEED, B. A. McClANE, G. SONGER, H. T. TRINH, F. M. E. MIYAKAWA, S. GARD (2008): Ulcerative enterocolitis in two goats associated with enterotoxin-and beta2 toxin-positive Clostridium Perfringens Type D. J. Vet. Diagn. Invest. 20, 668-672.

UZAL, F. A., J. E. VIDAL, B. A. McCLANE, A. A. GURJAR (2010): Clostridium perfringens toxins involved in mammalian veterinary diseases. Open Toxinology J. 2, 24.

VAN ASTEN, J. A. M., C. W. VAN DER WIEL, G. NIKOLAOU, D. J. HOUWERS, A. GRÖNE (2009): A multiplex PCR for toxin typing of Clostridium perfringens isolates. Vet. Microbiol. 136, 411-412.

VAN ASTEN, J. A. M., G. N. NIKOLAOU, A. GRÖNE (2010): The occurrence of cpb2-toxigenic Clostridium perfringens and the possible role of the $\beta 2$-toxin in enteric disease of domestic animals, wild animals and humans. Vet. J. 183, 135-140.

VILEI, E. M., Y. SCHLATTER, V. PERRETEN, R. STRAUB, M. R. POPOFF, M. GIBERT, A. GRÖNE, J. FREY (2005): Antibiotic-induced expression of a cryptic cpb2 gene in equine $\beta 2$ toxigenic Clostridium perfringens. Mol. Microbiol. 57, 1570-1581.

WANI, S. A., M. A. BHAT, R. NAWCHOO, Z. H. MUNSHI, A. S. BACH (2004): Evidence of rotavirus associated with neonatal lamb diarrhea in India. Trop. Anim. Health Prod. 36, 27-32.

WANI, S. A., I. SAMANTA, Z. H. MUNSHI, M. A. BHAT, Y. NISHIKAWA (2006): Shiga toxinproducing Escherichia coli and enteropathogenic Escherichia coli in healthy goats in India: occurrence and virulence properties. J. Appl. Microbiol. 100, 108-113.

WATERS, M., A. SAVOIE, H. S. GARMORY, D. BUESCHEL, M. R. POPOFF, J. G. SONGER, R. W. TITBALL, B. A. McCLANE, M. R. SARKER (2003): Genotyping and phenotyping of beta2-toxigenic Clostridium perfringens fecal isolates associated with gastrointestinal diseases in piglets. J. Clin. Microbiol. 41, 3584-3591.

YANG, D. K., I. J. HWANG, B. H. KIM, C. H. KWEON, K. W. LEE, M. I. KANG, C. S. LEE, K. O. CHO (2008): Serosurveillance of viral diseases in Korean native goats (Capra hircus). J. Vet. Med. Sci. 70, 977-979.

Vet. arhiv 88 (1), 1-20, 2018 
D. D. Singh et al.: Molecular detection of Clostridium perfringens toxinotypes, EPEC, rota- and coronavirus in diarrheic goat kids

Received: 27 October 2016

Accepted: 11 October 2017

SINGH, D. D., R. S. PAWAIYA, K. GURURAJ, N. K. GANGWAR, A. K. MISHRA, D. ANDANI, M. K. SINGH, S. BHUSHAN, A. KUMAR: Molekularni dokaz toksinskih tipova bakterije Clostridium perfringens, enteropatogenih sojeva Escherichia coli te rotavirusa i koronavirusa u uzorcima proljeva kod neonatalne jaradi. Vet. arhiv 88, 1-20, 2018.

\section{SAŽETAK}

U populaciji od 1156 neonatalnih jarića 238 je pokazivalo kliničke znakove proljeva. Od njih su uzeti uzorci izmeta za dokazivanje toksinskih tipova bakterije Clostridium perfringens, enteropatogenih sojeva bakterije E. coli (engl. enteropathogenic E. coli, EPEC), rotavirusa skupine A (engl. group A rotavirus, GARV) i goveđeg koronavirusa (engl. bovine coronavirus, BCV). Izdvajanje i toksinska tipizacija izolata provedeni su višestrukom lančanom reakcijom polimerazom (PCR) upotrebom početnica za gene $c p a, c p b, c p b 2$, etx i iap. Izdvajanje i identifikacija EPEC-a provedeni su pretragom na gen $b f p \mathrm{~A}$ i PCR-om u stvarnom vremenu, uz upotrebu SYBR zelenila (qPCR). Za dokaz rotavirusa skupine A i goveđeg koronavirusa upotrijebljena je RTPCR (osRT-PCR). Incidencija bakterije $C$. perfringens iznosila je $15,13 \%$. Od toga je $75 \%$ izolata pripadalo toksinskom tipu A, $25 \%$ tipu D, dok je 61,11 \% izolata imalo gen za toksin $\beta_{2}$. Incidencija EPEC-a iznosila je $68,07 \%$, a $21,85 \%$ pretraženih uzoraka bilo je pozitivno na GARV te $15,97 \%$ na BCV. Mješovita infekcija bakterijom C. perfringens i EPEC-om utvrđena je u 11,76 \% uzoraka, C. perfringens i GARV u 3,78 \% te $C$. perfringens i BCV u 2,1 \% pretraženih uzoraka. Mješovita infekcija EPEC-om i GARV-om utvrđena je u 19,74 $\%$, a EPEC-om i BCV-om u 11,34 \%. Mješovita infekcija rotavirusom i koronavirusom bila je ustanovljena u 5,88 $\%$, a mješovita infekcija EPEC-om, GARV-om i BCV-om u 4,20 \% uzoraka. Od ukupnog broja pretražene jaradi s proljevom u njih $0,84 \%$ dokazana je mješovita infekcija bakterijom $C$. perfringens, rotavirusom skupine $\mathrm{A}$, goveđim koronavirusom i EPEC-om. Na osnovi prikazanih rezultata može se zaključiti da izdvajanje, višestruki PCR te PCR u stvarnom vremenu omogućuju karakterizaciju i praćenje kolanja toksinskih tipova bakterija $C$. perfringens i EPEC-a u koza uzgajanih u sušnim uvjetima. Važnost enteritisa uzrokovanog rotavirusom skupine A i goveđim koronavirusom te njihova uloga kod mješovitih infekcija u koza zahtijevaju pojačan nadzor i istraživanje patogenosti radi povezivanja kliničkih znakova s ustanovljenom bolešću.

Ključne riječi: $C$. perfringens; toksinski tipovi; E. coli; rotavirus; koronavirus; neonatalni proljev; koze 